\title{
The Obstacles that Become the Problem in Implementing A Complete Systematic Land Registration (PTSL)
}

\author{
RACHMAT DWI HENDRATNO \\ I GUSTI AYU KETUT RACHMI HANDAYANI
}

Sebelas Maret University Surakarta, Indonesia

\begin{abstract}
Abstrack
The paper aims to examine the potential obstacles to problem of complete systematic land registration(PTSL) as the goverment's priority agenda to establish land registration throughtout indonesia. This study uses a normative legal research approach by analyzing the legistlation related to land registration. Espesially PP. 24 of 1997 concering lan registration and Ministerial Regulation ATR/Ka. BPN No. 12 of 2017 as amended by Ministerial Regulation No. 6 of 2018. The potential of this problem relates to the issue of tax and income tax payable, human resources, facilities and infrastructure, issues absentee land, maximum excess of land ownership, abandoned land, announcement of physical and juridical data, and problems of application of the principles of contradictoire delimitation. The potential of this problem is describedand is given alternative solutions on the implementation of PTSL. Alternative solution is by strengthening the regulation of PTSL in the form of Government Parliament (PP), either by revising PP. 24 of 1997 and byforming a separate PP on PTSL by clarifying the outlined problems.
\end{abstract}

Keywords: PTSL, Legal Protection, Legal Certainty

\section{Introduction}

Implementation of land registration in all of Indonesia region is government's duty and right holder under article 19, 23, 32, and 38 Agrarian Law. Land registration is a requirement to achieve legal certainty and legal protection of the right over the land, as stipulated by Sutedi $(2011,27)$ to create legal certainty must meet these requirements: a) There is a clear and consistent rules; b) Government institutions applies law consistently, adhere and comply it; c) Good behaviour in society based on the law; d) independent Judges, impartiality and must apply the law consistently as well as carefull when settle law dispute; e) Court verdict must be executed in concrete. While legal protection for right holder over the land can be conducted as meet these cummulative requirement : (1) Issuance of land certificates is 5 years or more, (2) process of issuance based on good will (3) Physically, the right holder or author has the land. (Santoso 2010, 280).

Land registration beside functioning to protect the owner, also to know the statue of the land, who the owner, what they right, how large the land, what for and etc. (Dalimunthe, 2000,123). Ensuring of legal certainty which will implemented in land registration includes statue certainty of right registered, subject's right certainty and object's right certainty. Land registration issues a certificate as a proof sign of its rights. (Santoso 2010,2).

In implementation to land registered in all Indonesia region, in fact it hasn't satisfied registration yet. Those things was stated on the first land registration of government instructions that was PP No. 10 year 1961 which has prevailed for 35 years, about 16,3 millions land registered of 55 million land (see detail in PP No. 24 year 1997). Thus, with prevailed of PP No. 24 year 1997 which accomplised from PP No. 10 year 1961, still no maximum in implementation of 126 millions land in Indonesia, only 46 millions which registered, it's means there was 80 millions land unregistered. While according to Van der Eng 2016 in Wahyuni, 2017 land increasing more than 1 million per year. ATR/BPN (National Land Agency) represent the Government has authority of land registration, attempts to accelerate land registration with various program/project with its limitations. The program/project which existed before such as, acceleration of land registration through Land Administration Project, Land Management and Policy Development Project (LMPDP) or adjudication, Larasita and National Agrarian Program hasn't get achievement.

The new program is Complete Systematic Land Registration (PTSL) that hold by Head of ATR/BPN (National Land Agency) which has target 126 millions land registered and certificated in whole in 2025 . Then it describes within 5 millions targeted in 2017, 7 millions land in 2018, 9 millions land in 2019 and 10 millions in each year till 2025. As normal routine registration in a year more than 500 thousands land needs 160 years for registering all the land (Purbaya, 2017). PTSL's targets is not easy duty, many opinion see it as ambition, personal branding and immediately politic interests. Those opinions refers to outcomes of land registrations today more that 50 percent registered. In fact more than 57 years ago the instructions to register the land as stipulated in Agrarian Law. 
If it analyzed in depth the main cause is goverment political will, previously land registration programs has been done in ministry level, not in top government that is President. Those distinguish PTSL program and previously program, president supervises, evaluates and give his hand in granting certificate on PTSL implementation.

For ensuring legal certainty and legal protection of PTSL program as well as to reduce dispute, ministry of ATR/BPN has accomplised various primary rules/ written rules, which is complete and clear, increase human resources, more quality and quantity of facilities, more financial, coordinates among the agencies out of BPN. Normatively, it has been regulated in law as facilities for providing simplicity and acceleration in land registration in Indonesia.

Even many regulations as "Law Umbrella" for PTSL has been issued and cooperation or coordination among the institutions has been built as well as breakthrough has been made, but in implementation level, still exist constraints in its implementation which quatity target oriented that allows disregarding quality. The constraints are Tax charges of land (PPh and BPHTB), human resources, facilities and infrastructures, absente land, overcapacity land, derelict land, problems in physical land announcement and juridical data and applied delimitation contradicture principles, from the constraints is described and provide solutions in PTSL implementation. The below questions will be focused of the review.

Review on this paper used normative research method with statute approach is a research that emphasizes material law in form regulations as basic references to conduct the research. The research was conducted by analyze consistency/adjustment of regulation that related with land registration that is PP No. 24 year 1997 and Ministry Regulation/Head of BPN No. 6 year 2018.

\section{A. Tax Charges of Land (PPh and Payable Charge of Property Title (BPHTB-terutang))}

Generally, process of land registration is not only BPN authority because there are relation among other institutions like as Financial Ministry concerning Income Tax ( $\mathrm{PPh}$ ) and Rural Government concerning Charge of Property Title (BPHTB) and Land Officer/Notary for making deed as a requirement for issuance the certificate. The requirements as $\mathrm{PPh}, \mathrm{BPHTB}$, Deed making are one of main factor of constraints in land registration. Until now, society assume that is expensive, long time and too complicate to administrate a certificate. The charges is so expensive because to pay deed, $\mathrm{PPh}$ and BPHTB, long proceed because it's need much time to process it, pay the tax, administration process in BPN, divagate to Land Officer, Pratama Tax, Revenue Agency, Finance and Vault Administration and BPN. To overcome it, it is conducted by one stop service when all of process are done in BPN Office (for instance Tax Office and Land Officer has their own places in BPN), so they can increase society motivation regarding land registration.

The definition of tax payable is in accordance with Article 1 Number (10) of Law No. 28 of 2007 is tax that must be paid at a time, in Tax Period, in Tax Year, or in the Part of Tax Year in accordance with the provisions of tax legislation. PPh and BPHTB Tax law support the legal regime, PPh is regulated in Law No. 28 of 2007 concerning the Third Amendment to Law No. 6 of 1983 concerning General Provisions and Tax Procedures along with the implementing regulations. Whereas BPHTB is regulated in Law No. 28 of 2009 concerning Regional Taxes and Regional Levies. In theory, as stated by Widyawati (2010), regulation in tax law is divided into two, material tax law and formal tax law. Material tax law governs the provisions regarding who is taxed, who is excluded, what is taxed and what is excluded and how much tax is payable. Whereas formal law regulates how to implement material tax law, regulates the procedures (procedures) for fulfilling tax rights and obligations.

Provisions for Income Tax payable are not regulated in Government Regulations, do not clearly state the time of tax payable, only stipulates that before the deed, minutes of auction or other letter signed by authorized official, evidence payment of PPh must be presented first. It is different from regulation in BPHTB which has clearly stated that the tax due arises when the deed, minutes of auction or other relevant letters are signed by authorized official, but on the other hand the authorized official is prohibited from signing the deed, auction minutes or other relevant letters before payment receipt of BPHTB is shown (Widyawati 2010).

In relation to PPh and Payable BPHTB in PTSL implementation of according to Darmawan $(2017,31)$ philosophy of tax amnesty needs to be emulated in process of systematic land registration complete by freeing the first time land registration from land taxes such as PPH and BPHTB, will accelerate collecting data in the form of land registration and the government will benefit in the form of land certificate data which is a source of tax object in the future. Furthermore Darmawan $(2017,31)$ states: (1) Every property / land transfer is taxable; (2) Transition does not have to be proven by deed, as long as there is a transition, it is subject to tax; (3) There is no payable tax. That view seems quite reasonable when seen from the latest provisions concerning Government Regulation No. 34 of 2016 concerning Income Taxes on Income from Transfer of Land and / or Building Rights and binding purchase agreement for land and / or buildings and their amendments. 
Providing a zero tax specifically for the first time land registration because in general the first time land registration is a poor community. This is in accordance with Ministerial Regulation ATR / Ka. BPN No. 261 / KEP-7.1 / XI concerning land rights certification for people who have a prosperous family card, as an effort by the government to improve welfare of community and make it easy in the service of land rights certification for the first time and provide ease in cost of measurement, transportation, accommodation, consumption, and land inspection fees (Committee A) which are charged to Budget Implementation Registration List (DIPA). Meanwhile, BPHTB is requested to regional administration to be released. This provision should be enforced or implemented as an effort to attract community interest in registering land, because it will facilitate the acceleration of land registration, indirectly encourage economic growth, minimize disputes, and will provide legal certainty guarantees and legal protection for apprentices of land rights if land has been registered.

This mechanism can be realized if there is sincerity and political will of the government that land registration throughout Indonesia territory in accelerating PTSL program as a priority agenda. According to Darmawan (2017), PTSL is a breakthrough in land registration. Gradually a complete village will be realized and this will become an embryo for realization of map of parcels in each location and realization of one map policy. Other institutions will get very large impact related to detailed spatial planning, LP2B determination, tax collecting, social / political maps, and others.

\section{B. Human Resources, Facilities and Infrastructure}

The need for human resources is crucial in successful implementation of PTSL, both in quality and quantity. Human resources in the land offices have various scientific aspects and are not evenly distributed, dominated in the regions of Java compared to outside Java. This should also be an evaluation material within Ministerial Regulation ATR / Ka. BPN. Not to mention the problem of routine land registration service routine work, number of land parcels increases every year in PTSL activities. This certainly needs to be calculated number of ASN with the volume of work, so that routine work and PTSL can go in line without ignoring routine activities.

The need for PTSL acceleration for Licensed Cadastral Surveyors (SKB) has been accommodated in Ministerial Regulation ATR / Ka. BPN No. 33 of 2016 as amended by Ministerial Regulation ATR / Ka. BPN No. 11 of 2017 concerning Licensed Cadastral Surveyors (SKB). Accelerating the supply of Assistant Cadaster Surveyors (ASK) also done through a short education of 2 or 3 weeks for graduates of Geomatics Vocational School conducted by BLK in collaboration with local BPN Regional Office. Another breakthrough is also needed to overcome the shortage of measurement officers, to empower and give the authority of Non-permanent Employees (PTT) by revising Perkaban No. 2 of 2014 concerning Non-Permanent Employees within the BPN RI Environment. Because the capacity has more ability in experience compared to ASK with a short education of 2 or 3 weeks for SMK graduates. Likewise, according to Ratmono $(2017,62)$ the work of collecting physical data through land parcels, in addition to being carried out by ASN, can be done by involving stakeholders, such as Joint Decree. Use of other surveyors, such as from Dit. Topography AD, Measurement and Mapping Service in OPD, Student of Geodetic / Geomatics, STPN, and others. Those need to be considered how the mechanism.

\section{Problems of Absentee Land, Maximum Excess, and Derelict Land}

Agricultural land ownership absentee / Guntai is a land ownership located outside the residence of the owner, for example, different regions or districts. Under legal provisions land absentees are obliged to transfer their rights to their land within a period of 6 months to other people in sub-district where the location of the land or the owner moves to another sub-district. Prohibition of absentee land ownership because it violates the principle in Article 10 of Agrarian Law which states that agricultural land must be actively worked or cultivated by the owner himself. Likewise, the principle of prohibition of ownership and authority of land that exceeds the limit (Article 7 of Agrarian Law) as an effort to prevent the accumulation of land in the hands of certain groups. And the prohibition on derelict land (Article 27 of Agrarian Law). But in reality there are still many people who have absentee agricultural land and land that transcends borders and abandons their land.

The policy to regulate absentee land and land that exceeds the limit has been carried out through the land reform program regulated in Law no. 56 of 1960 along with the implementing regulations by taking over excess land from the maximum limit and absentee lands, which are then planned to be distributed to groups of people who do not have land (Ismail 2012). Whereas the aquisition of derelict lands is regulated in PP No. 11 of 2010, but in its implementation of controlling derelict lands there are still many lawsuits in court which are generally won by right holders because in the aspect of formal procedures the stages are not obeyed and are considered as juridical defects (Mujiburohman 2015, 142). 
Besides the implementation of PTSL, it should identification and inventory is also carried out absentee land, maximum excess land and derelict land as mandated by the Instruction of the Minister of Agrarian Affairs / Head of the National Land Agency No. 2 of 1995 concerning Inventory of Derelict Land, Maximum Excess Land and New Absentee. Identification and inventory as initial data to bring order in accordance with applicable laws and regulations. At least to regulate absentee land, maximum excess land and derelict land is carried out by: a) conducting counseling to the community related to the prohibition of having absentee land, maximum excess land and derelict land in coordination with the village / kelurahan; b) recording each parcel of land to determine the subject and object of the land; c) curbing is done by voluntary release or revocation of land rights by providing compensation and the land is controlled by the state and distributed to those entitled to receive it and or the land is kept as a land bank.

On the other hand, absentee land and derelict land can obstruct the measurement of land parcels because most of the land is an investment and holders of rights not domiciled in their land area, so it needs to be identified, inventoried, and regulated. However, issuance is not an easy matter, because it requires large costs. For this reason, the government must play an active role in monitoring and controlling of land administration, reducing gaps of land ownership, and even reducing land disputes.

Bookkeeping and issuance of certificates of land rights for absentee land and maximum excess land under PTSL implementation is included in category three (K-3), i.e. land parcels for which physical data and juridical data cannot be recorded and issued certificates, because the subject of his rights must first meet certain requirements and land registration data must always be adjusted to the use and utilize of land Existing (Article 25, Article 28 and Article 30 of Ministerial Regulation ATR / Head of BPN No. 6 of 2018). As the final purpose of land registration is the issuance of a certificate as proof of a strong right or the intended category one (K-1), that is, parcels of land for which physical data and juridical data meet the requirements for the issuance of the Land Rights Certificate

\section{Announcement of Physical Data and Juridical Data}

PTSL activities strongly demand legal certainty. One of important issues related to legal certainty is principle of publicity which has differences in regulation between government regulations and ministerial regulations. To fulfill the principle of publicity in proving land ownership, the announcement of physical data and juridical data is carried out for 14 (fourteen) calendar days (Article 24 of Ministerial Regulation ATR / Head of BPN No. 6 of 2018). This provision is different from Article 26 PP No. 24 of 1997 concerning Land Registration which requires 30 days and Article 63 PMNA / Ka. BPN No. 3 of 1997 concerning Provisions for Implementing Government Regulation No. 24 of 1997 concerning Land Registration.

Different publicity principle arrangements provide a potential for future disputes, due to the principle of regulation the

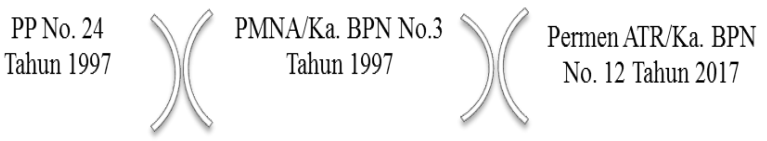

lower should not conflict with higher regulations. According to Soeprapto $(2010,41)$ based on the theory of the level of legal norms put forward by Hans Kelsen that is stufentheorie, which states that legal norms are tiered and multi-layered in a hierarchy, where a lower norm applies, sourced and based on higher norms, higher norms apply, sourced and based on even higher norms, and so on until they reach a norm called the basic norm (grundnorm). In line with Sitorus (2017, 10) states, the asynchronization invalidates the lower legal rules, but in practice the state asynchronous rules does not automatically cancel the lower rules before the lower rules are canceled by competent court in conducting a judicial review. For this reason, Ministerial Regulation on PTSL remains in effect before a judicial review decision from Supreme Court.

In government perspective, announcement of physical and juridical data for 14 calendar days is still too long, opening possibility to shorten the announcement when referring to Presidential Instruction No. 2 of 2018 concerning Acceleration of Complete Land Registration which principally governs Ministry of ATR / BPN to revise / amend Ministerial Regulation ATR / Ka. BPN No. 12 of 2017 related to: a). Categories of K1 through K4 were revised into 3 clusters, b) Make regulations and take steps to resolve PTSL acceleration in the process of proving and / or control of land, c) make / prepare / revise regulations governing the period of announcement of physical data and juridical data to accelerate PTSL completion, d) submit PTSL output to strengthen one map policy database, e) periodically evaluating and monitoring and reporting to president.

However, ATR / Ka. BPN No. 6 of 2018 as a result of revision of Ministerial Regulation ATR / Ka. BPN No. 12 of 2017, there are still no substantive changes as requested in Presidential Instruction No. 2 of 2018, changes are only at the normative level. Still use K1 to K4 cluster system (Article 25); The period of announcement of physical data and juridical data is still the same as 14 calendar days (Article 24); 
PTSL acceleration completion steps are only accommodated in separate Chapter $\mathrm{V}$, substantially there is no change with Ministerial Regulation ATR / Ka. BPN No. 12 of 2017; Likewise, the PTSL output that is set too short is only one paragraph in Article 38 paragraph (3) stating the results of PTSL activities are also conveyed to the One Map Policy Acceleration Team to strengthen the One Map Policy database.

Contradictory regulations between Ministerial Regulation ATR / Ka. BPN No. 6 of 2018 with PP No. 24 of 1997 concerning the time of announcement of physical data and juridical data. This provision when viewed from the principles of the legislation can be described as follows: First, the principle of lex superior derogat legi inferior which means that the higher regulation overrides the lower one (the hierarchical principle), then the PP 24 of 1997 is used because more PP a higher degree than a Ministerial Regulation, because the provisions of Ministerial Regulation are lower in degree, cannot change or override the provisions of a higher degree PP, even a ministerial regulation has no legal force and is not binding if the content is contradictory with PP; secondly, Lex Specialis Derogat Legi Generali principle, principle of special law disregarding general law, also cannot be applied in use of this principle because lex specialis provisions must be equivalent to the provisions of lex generalist, for example, act with act, PP with PP, etc; third, Principle of Lex Posterior Derogat Legi Priori, this principle is also for equivalent rules, most recent rules crippling old rules.

The next issue is how power to bind Minister Regulation ATR / Ka. BPN No.6 of 2018. Referring to Article 8 verse (2) of Law no. 12/2011 confirms: "Legislation as referred to in paragraph (1) is recognized and has binding legal force insofar as it is ordered by higher Regulations or formed based on authority". In this provision there are two conditions so that ministerial regulations have binding power as statutory regulations, which are ordered by higher legislation or formed based on authority. When referring to Article 19 of Agrarian Law, PTSL activities are mandated by Article 19 of Agrarian Law as a source of legal ministerial regulations. This means that lower regulations must not contradict higher regulations.

\section{E. Hardly to Apply Delimitation Contradictory Principle}

An activity in the placement of land parcels based on agreement of the parties concerned in land registration is called Contradictoire Delimitatie principle. Delimitation contradiction is a norm used in land registration by requiring land rights holders to pay attention to placement, determination and maintenance of land boundaries based on agreement and dealing of the parties concerned, in this case the land owners who border the land they own. If the owners of land bordering do not get an agreement with actual location of a boundary even though mediation has been carried out, then determination of the boundary with decision of the court (Articles 17, 18, 19 PP No. 24 of 1997). Therefore agreement / approval and presence of land owners who neighbour are obligations in the registration of land.

Application of Delimitation Contradictory Principle goes well when the parties has an interest in attending and giving approval in determination of boundary markers. But in reality it is different, the application of delimitation contradictory principle experiences difficulties in the field, both in carrying out routine land registration as usual and in PTSL program. Some of difficulties factors that cause principle of delimitation contradiction cannot be implemented properly, among others: First, the holder of land rights does not maintain boundaries of good parcels of land which have become obligations that cause overlapping boundaries of the parcels, due to unclear parcels of land or boundaries that have been fitted with stakes lost, lack of public awareness to maintain boundary marks; secondly, the parties were not present at the time of the land boundary determination, due to the busyness of the land owner and or difficulty in finding the land owner due to absentee land ownership; third, land disputes, family or neighbor disputes and the disputes that have entered the court. These problems obstruct measurement process.

\section{F. Evidence of Rights}

Evidence of rights in PTSL implementing is regulated in Article 22 of Ministerial Regulation/BPN No. 6 of 2018. The issue is related to a written statement about ownership and / or physical authority over land parcels in good will in the case that evidence of land ownership is incomplete or nonexistent.

Provisions of Article 22 require a written statement regarding physical authority of land and in good will. A statement of physical ownership of land must be witnessed by at least 2 (two) witnesses from the local environment who are not related by family and can be held accountable both civil and criminal. If in the future there is an element of untruth in the statement, it is not the responsibility of PTSL Adjudication Committee. This provision can be interpreted as follows:

(a) The physical tenure of land is for 20 (twenty) years or more respectively not less than 20 years and or as high as the time lag, for example, the new tenure is due to certain events shifted to another party, then even wants to return to original tenure 20 years, and authority of the land is not contested by other parties in accordance with Article 24 paragraph (2) PP No. 24 of 1997. 
(b) A statement of physical tenur over land must be witnessed by at least 2 (two) witnesses. This provision has the potential to falsify a statement should be strengthened by testimony of people who can be trusted, for example witnessed by 2 witnesses and known by RT, RW, and village / village. There are legal consequences if it is found to falsify the contents and the signing of a statement that is willing to be prosecuted before a criminal or civil judge for providing false information.

(c) If there is an element of incorrect statement letter is not responsibility of PTSL Adjudication Committee. This is a form of self protection from law by PTSL Adjudication Committee and this can be justified because in the evidentiary aspect it does not have the authority to test material rights regarding the truth of statement, only formal testing rights regarding the administrative requirements. For example, checking the statement has been signed by parties, the truth about suitability between the people who signed it is not the authority of Adjudication Committee.

On the other hand, regulation of Physical Land Acquisition Statement must also take into account other regulations such as Regional Regulations (Perda). Because there are certain regions regulating Statement of Physical Acquisition of Land consists in the form of a Regional Regulation. For example, Regional Regulation of Tanah Bumbu Regency. No. 13 of 2016 concerning Registration of Physical Land Acquisition Statement, which regulates or requires registration obligations, procedures, prohibitions and supervision, reporting and sanctions in terms of registration or recording from the applicant in order to obtain the Register Number of Physical Land Acquisition Statement from the village / subdistric to realize orderly administration of land in the village.

To minimize land dispute cases, role and coordination of the village / subdistrict should not be neglected in making a Physical Land Acquisition Statement as a formal proof of land tenure in good will, there must be recognition and justification by the customary law community or village / subdistrict.

Furthermore, element of good will from the fact of physically acquisition, usage, utilizing, and maintaining land for generations in a certain time and / or obtaining by not violating the provisions of legislation. Good will is proven by statement of applicant / PTSL adjudication participant stating: a). there is no objection from other parties over land owned or not in dispute; and b). not included or not an asset of Government, Regional Government, or State-Owned Enterprise / Regional-Owned Enterprise; or Forestry Area (Article 22).

\section{G. Conclusion}

Various regulations were made and accomplished in PTSL implementation to create legal certainty and legal protection, as well as to minimize disputes. However, at implementation level there are still obstacles that have potential to become problems in the future, including: regarding Land Tax ( $\mathrm{PPh}$ and payable BPHTB), human resources, facilities and infrastructure, absentee land issues, maximum excess and derelict land, announcement issues physical data and juridical data, problem of applying principle of delimitation contradiction and proof of rights. These problems have potential to cause a dispute one of the reasons is position of Ministerial Regulation ATR / Ka. BPN No. 6 of 2018, when reviewed in theory of hierarchy of laws and regulations has a lower degree compared to the problem settings that have been described above. On the other hand, contents in the Ministerial Regulation ATR / Ka. BPN No. 6 of 2018 there is a conflict with higher regulations..

An alternative solution to describe legal and implementation problems by strengthening legal basis for PTSL implementing with PP, by revising / changing PP No. 24 of 1997 concerning Land Registration and / or PTSL implementation is regulated separately in PP, so that legal degree of PTSL implementation is higher with Ministerial Regulation. Because in principle the legislation can be applied several,: first, Lex Specialis Derogat Legi Generali principle, special regulations that can disregarding general rules and provisions in general legal rules remain in force, except those specifically regulated in the special legal rules. For example, regulations on PPh and BPHTB which have a legal regime in place, of course the implementation of PTSL regarding PPh and BPHTB can use Lex Specialis Principle if PTSL regulations are in the form of PP. Secondly, Lex Superior Derogat Legi Inferior principle, which means that higher regulation disregarding lower one, this also relates to existence of a Regional Regulation when compared with ministerial regulation, its legal position will always be a matter of debate. It is different if PTSL implementation regulations uses PP, then Perda can be set aside.

\section{Bibliography}

Ismail, N 2012, Arah politik hukum pertanahan dan perlindungan kepemilikan tanah masyarakat (Political direction of land law and protection of people's land ownership) Jurnal RechtsVinding Volume 1 No. 1.

Dalimunthe, C 2000, Pelaksanaan landreform di indonesia dan permasalahannya, FH USU Press, Medan. 
Darmawan, DA 2017, "Identifikasi masalah dan catatan kritis: Pengalaman pelaksanaan pendaftaran tanah sistematis lengkap (PTSL) di Kabupaten Sidoarjo", Prosiding seminar nasional percepatan pendaftaran tanah di indonesia: Tantangan pelaksanaan PTSL dan respon solusinya, Sekolah Tinggi Pertanahan Nasional (STPN), YOgyakarta.

Mujiburohman, DA 2015, Potensi dan permasalahan pulau sangiang sebagai objek tanah terlantar, Bhumi, Volume 1, No.2, Yogyakarta.

Ratmono 2007, "Pelibatan masyarakat dan stakeholder terkait dalam percepatan pelaksanaan Pendaftaran Tanah Sistematis Lengkap (PTSL)", Prosiding seminar nasional percepatan pendaftaran tanah di indonesia: Tantangan pelaksanaan PTSL dan respon solusinya, Sekolah Tinggi Pertanahan Nasional (STPN), Yogyakarta.

Santoso, U 2010, Pendaftaran dan peralihan hak atas tanah, Kencana, Jakarta.

Santoso, H 2017, "Percepatan pendaftaran tanah di Indonesia: tantangan pelaksanaan PTSL dan respon solusinya", Prosiding seminar nasional percepatan pendaftaran tanah di indonesia: Tantangan pelaksanaan PTSL dan respon solusinya, Sekolah Tinggi Pertanahan Nasional (STPN), Yogyakarta. 